\title{
Digesting the Message about Contaminants and Country Foods in the Canadian North: A Review and Recommendations for Future Research and Action
}

\author{
C.M. FURGAL, ${ }^{1}$ S. POWELL ${ }^{2}$ and H. MYERS ${ }^{2}$
}

(Received 3 September 2003; accepted in revised form 28 July 2004)

\begin{abstract}
Communicating the risks of environmental contaminants in the food chain to northern Aboriginal peoples poses significant challenges for communities at risk and environment and health professionals alike. Reported results of poor risk communication practice on this issue include increased fear and confusion in northern communities, changes in the dietary behaviour and traditional lifestyles of their residents, and associated impacts on their society, economy, and health. A review of past communication research and activities on this issue in the Canadian North reveals a general ad hoc "learning by doing" approach to primarily one-way communication events. The lack of focused communication research on an issue that has garnered great focus and effort elsewhere in the country and continent has forced health professionals and communicators to rely on assumptions about the reception and level of comprehension of important health messages previously disseminated. The importance of this information is increasing as research begins to detect subtle health effects from exposure to these substances among newborns in some northern regions. Thus planning and evaluation are needed for risk communication, and possibly changes to the scale at which communication work is done in northern communities.
\end{abstract}

Key words: environmental contaminants, health, risk communication, comprehension, evaluation, environmental health, communication research, country/traditional foods

RÉSUMÉ. Le fait d'informer les peuples autochtones du Nord des risques associés à la présence de contaminants de l'environnement dans la chaîne alimentaire pose un défi de taille pour les collectivités exposées à ces risques, tout comme pour les professionnels de l'environnement et de la santé. Les résultats déjà rapportés d'une piètre pratique de divulgation des risques sur cette question mentionnent une augmentation de la peur et de la confusion dans les collectivités nordiques, des changements dans le comportement alimentaire et le style de vie traditionnel des résidents, et les impacts qui en résultent sur leur société, leur économie et leur santé. Un examen de la recherche en communications et des activités de divulgation antérieures sur cette question dans le Nord révèle que la communication est principalement unilatérale et se fait de façon improvisée sur le tas. Le manque d'une recherche en communications bien ciblée, sur une question ayant pris beaucoup d'ampleur et donné lieu à une importante mobilisation ailleurs à l'échelle du pays et du continent, ce manque donc a obligé les professionnels de la santé et les spécialistes en communications dans le domaine à se fier à des hypothèses quant à la réception et au niveau de compréhension d'importants messages relatifs à la santé diffusés antérieurement. Cette information acquiert de plus en plus d'importance à mesure que la recherche commence à détecter des effets ténus sur la santé dus à une exposition à ces contaminants chez les nouveau-nés dans certaines régions du Nord. Il faut donc procéder à une planification et à une évaluation de la divulgation des risques, voire à des changements dans l'échelle à laquelle s'effectue la communication dans les collectivités du Nord.

Mots clés: contaminants de l'environnement, santé, divulgation des risques, compréhension, évaluation, santé environnementale, recherche en communications, aliments du terroir/nourriture traditionnelle

Traduit pour la revue Arctic par Nésida Loyer.

\section{INTRODUCTION}

The presence of contaminants in the Canadian Arctic environment has received increasing attention over the past few decades primarily because of potential risks to human health from contamination of traditional or country foods. The long-range transport of contaminants by wind and ocean currents has brought to the Canadian North measurable amounts of pesticides, heavy metals, and radionuclides, which are then deposited into various compartments of the environment via precipitation and atmospheric deposition (Barrie et al., 1999; Van Oostdam et al., 2003). These substances can accumulate in Arctic biota and are magnified as they move up the food chain,

\footnotetext{
${ }^{1}$ Unité de recherche en santé publique (Centre hospitalier universitaire de Québec - Centre hospitalier de l'Université Laval) et Département Science Politique, Université Laval, 945 Ave Wolfe, Ste. Foy, Québec G1V 5B3, Canada; Christopher.Furgal@crchul.ulaval.ca

${ }^{2}$ Department of International Studies, University of Northern British Columbia, 3333 University Way, Prince George, British Columbia V2N 4Z9, Canada

(C) The Arctic Institute of North America
} 
ultimately into species that are important traditional food sources for indigenous peoples residing in the North (Braune et al., 1999; Muir et al., 1999; Van Oostdam et al., 2003). In fact, the primary exposure to contaminants for Arctic residents is through the traditional northern diet, which consists primarily of long-lived marine and land mammal species (Van Oostdam et al., 1999, 2003). This exposure and the knowledge of these contaminants in traditional foods pose risks to the physical, social, and mental health and well-being of Northerners. Determining the risks and benefits of country food consumption in the face of environmental contamination requires the explicit consideration not only of the type and amount of foods consumed, but also of the sociocultural, nutritional, economic, and spiritual benefits provided by these food sources (Van Oostdam et al., 1999, 2003).

The management and communication of the risks posed by environmental contaminants in the food chain of Northerners pose a challenge for health and environmental managers and health professionals. Traditional food is the anchor to cultural and personal well-being in the North. It is essential to the nutritional and social health of Aboriginal individuals (Kuhnlein and Souieda, 1992; Condon et al., 1995). Research shows that these foods are significant sources of protein and essential vitamins and may help protect Northerners against cardiovascular disease and the toxic effects of exposure to mercury (Dewailly et al., 2000; Van Oostdam et al., 2003). Further, many communities and some subgroups of the population lack available and accessible healthy alternatives to these foodstuffs. However, despite the vital importance of traditional food sources, significant changes in their collection, use, and consumption and in the attitudes towards these food sources have occurred over the past two decades (Berkes and Farkas, 1978; Kuhnlein and Souieda, 1992; Kinloch et al., 1992; Condon et al., 1995). These changes have accompanied other significant evolutions in the Arctic economy and lifestyles. Some of this change related to traditional foods can be attributed to the presence of industrial pollutants in the Arctic ecosystem and the strategies used to manage and communicate concerns about human exposure to these contaminants (Kinloch et al., 1992; Jetté, 1994; Furgal, 1999). Some past risk management and communication strategies reportedly have resulted in fear and confusion among community residents and have had significant social, economic, and health impacts (both direct and indirect) on the communities involved (Wheatley and Wheatley, 1981; Kinloch et al., 1992).

This paper reviews well-known cases of risk communication activities in northern communities to discuss what we have learned, both there and elsewhere, about communicating risks of contaminants. It then proposes a framework and strategies for judging the effectiveness of risk communication activities in the Canadian North and indicates future needs for research and practice.

\section{CHALLENGES OF COMMUNICATING ABOUT CONTAMINANTS IN THE NORTH}

\section{Complexities of Communicating in Northern Communities}

Communicating about the risks of contaminants in the North is not an easy task. Factors operating in northern Canadian communities that challenge this exercise include the barriers of obvious cultural differences, e.g., in language and knowledge systems, and the nature of small remote communities.

The most obvious factor in communication, of course, is cultural difference. Northern Aboriginal peoples are intensely involved with their environments as defining elements of their identity, as sources of valued food and work, and as their known space. Related to this is the importance of country food for its nutritional, economic, and sociocultural values (e.g., AMAP, 2003). The profound importance of country food makes the conduct of risk communication programs even more important, because the disruption of country food production, sharing, and consumption patterns can have serious effects on health and society in northern communities.

Language differences exist in a number of forms. Besides the language barrier between English and Aboriginal languages, there are also different levels of language facility within northern populations. Children and youth, and even some middle-aged people, may not be fluent in the traditional mother tongue, while some elders may not speak English at all. Others may be caught in between, without fluent mastery of either language. This diversity has been a general problem in cross-cultural communication. In addition, many languages, including Inuktitut, do not have equivalent terminology for English words referring to scientific concepts and chemical contaminants (Powell and Leiss, 1997). The inadequacy of terminology is compounded by definite differences in the concepts of Aboriginal (e.g., Inuit) and southern scientists, as well as in their respective outlooks on areas such as food, health, and relationships with animals and the land (Powell and Leiss, 1997).

Forms of knowledge in northern communities are different from knowledge systems found in the South, upon which many scientific findings related to these issues are based. Even in southern Canadian communities, it is often a problem for the general population to grasp scientific concepts, but in northern communities, such information is also being layered onto an entirely different worldview and mode of understanding. Traditional knowledge explains the world on the basis of centuries of observation, oral interpretation, and passing on of events and patterns, with an emphasis on the observable and a belief that humans and the physical/biological world are completely intertwined (e.g., Freeman, 1992; Usher, 2000). More recently, this knowledge system has become known in Inuit regions as Inuit Qaujimajatuqangit (IQ) — Inuit ways of knowing, ways of being, and worldview-past, present 
and future (McGrath, 2003). Therefore, when southern scientists introduced communities to the issue of contaminants in the environment, a concept based on "invisible" knowledge that could not be visually validated, many northern residents had difficulty believing, comprehending, and trusting this message (O'Neil et al., 1997). As a result, contaminant information and advice provided by scientists and outside sources is often received with varying degrees of scepticism, suspicion, and mistrust (O'Neil et al., 1997; Powell and Leiss, 1997). Confusion about local versus long-range sources of contamination is another consequence of poor communication. Many Inuit residents of the North view long-range contamination as an external threat to the Inuit way of life (O'Neil et al., 1997). Further, northern communities fear that efforts by southern scientists and authorities to assess and manage risks of contaminants in the North will result in further disruptions and little benefit for local residents (Powell and Leiss, 1997). This view, combined with the more holistic value system that governs human-environmental relationships in the North, implies that Northerners hold different perspectives on what is "useful" or pertinent knowledge relating to such risk issues.

Finally, characteristics of northern communities and Inuit societies themselves govern how communication takes place. Being small and isolated, these communities enjoy thriving informal communication networks, carried out as people work and visit daily with family and friends. News travels very fast. Such communities also lack access to specialized or expert information and resources, either because it is not available locally (except sporadically), or because it is often available in a language or format that is not easily accessible. Usher et al. (1995) identified "contaminants gossip" as an element of small northern communities. Information gets passed around though it is not necessarily accurate, and in fact, like gossip, may become inflated, exaggerated, or transformed. Further, some argue that as Inuit society and culture are not information-based, a relational approach to communication is the most appropriate and relevant for northern communities (McGrath, 2003). However, just as the information age has changed communication in other parts of the world, similar changes have taken place recently in the Canadian North. With greater access to such media as cable television, the Internet, and other forms of communication technology, small communities once isolated from the popular media are now inundated with messages and information concerning issues such as health, the environment, and the economy. This surge of information has created a competitive environment for communicators vying for audience attention (a problem that is just as challenging elsewhere in the world).

Further complicating the communication of contamination issues to northern communities is the fact that there is no "one North." Rather, the Canadian North is a cultural, economic, social, and demographic patchwork of diverse regions and communities. Just as there are many differences between northern Aboriginal communities and more urban centres in the South, there are many similarities as well in this age of rapid technological development. For example, many youth in the North are exposed to many of the same media-based influences and aspire to the same goals as their peers in the South. This dynamic nature of communities and individuals is important to note, as it makes the issue of engaging individuals in communication more complex than it would be if northern communities were purely static, traditional societies.

\section{Challenges of Discussing the Concept of "Risk"}

The task of communicating about contaminants in traditional foods in northern communities is further complicated by the need to relate the concept of "risk" across cultures and contexts. Some of the challenges experienced are common to the practice of risk communication anywhere; others, however, are unique to the specific issue and the context of northern Aboriginal communities.

Risk, in any context, is often a difficult concept to explain and communicate to the public. Social and cultural factors influence the reception and comprehension of risk messages. The idea that potential health risks are associated with a food supply and way of life previously regarded as "safe" has proved exceptionally difficult to convey to Aboriginal people in the North. The social context surrounding food in northern cultures makes this potential risk a threat to the daily lives of people who have relied on their ability to locate and acquire food and determine whether it is suitable for consumption through observation-based knowledge. Conveying the ideas of "levels of safety" or "probabilities of risk" has proven a further challenge, in that the daily assumption of risk in many northern communities is quite different from that of the southern scientists and health professionals who study contaminant issues. Many of the people now receiving messages about the safety of their foods have grown up living, hunting, and traveling on the land in a harsh and often dangerous environment. Thus, the cultural comprehension of what is "risky" behaviour has confounded the explanation of food safety in many cases. Aboriginal people in the North have little experience with food safety issues similar to that of contaminants in traditional foods. Perhaps the only comparable food risks that are familiar are hypervitaminosis from polar bear liver (high in vitamin A) and poisoning from shellfish harvested in shallow, warm waters or from spoiled canned foods (from damaged cans). Traditional knowledge of these risks is passed down and appears to be common knowledge among northern populations in some regions (e.g., Labrador; LIA, 1997). The transmission and verification of this knowledge is probably conducted via relationships between individuals, as discussed by McGrath (2003), and not simply by unidirectional dissemination of information.

The risk literature reports other factors that have influenced the ability of health professionals to relate these issues to northern communities. Examples are the history 
of how past cases have been dealt with in these communities, public trust in the authority dealing with the issue, the perception of the seriousness of the risk and the drama attached to it, whether the risk is associated with voluntary or involuntary exposure, and the perception of control over the risk (Johnson and Covello, 1987; Slovic, 2000).

\section{COMMUNICATION LESSONS FROM COMMUNITIES}

The initial discovery, management, and communication of the risks incurred by Northerners who consume country food species high in certain environmental contaminants had significant impacts (direct and indirect, intentional and unintentional) on the affected populations. The impacts reported include a shift away from country food consumption, an increase in economic hardship associated with reduced hunting and fishing activity and greater need to purchase market foods, and an increase in stress and anxiety among individuals in the community (Wheatley and Wheatley, 1981; Kinloch et al., 1992; Wheatley, 1993; Usher et al., 1995). Initial management processes involved reacting to the identification of a source of exposure, delineating the pathways and extent of exposure among the local population, taking decisions based on the potential risks of the contaminants, and managing these risks through consumption advisories to reduce exposure levels (Wheatley and Wheatley, 1981; Kinloch et al., 1992; Usher et al., 1995; Powell and Leiss, 1997).

The recognition of human health risks related to contaminant exposure in the territorial North and northern regions of Nunavik (Arctic Quebec) and Labrador first emerged in the late 1970s (Wheatley and Wheatley, 1981). Elevated mercury levels in residents of Sugluk (Salluit), Nunavik, due to consumption of fish high in mercury concentrations, raised concern for potential human health effects. The Medical Services Branch of Health Canada, finding high levels of mercury in Inuit and also elevated levels in sea mammals, advised residents to decrease consumption of certain species to limit their exposure (Wheatley, 1993). The release of this health advisory resulted in a certain amount of social, psychological, economic, and lifestyle disruption during the time immediately following the event (Wheatley, 1993).

A number of lifestyle changes for Sugluk residents resulted from the health advisories and alarming media reports. According to Wheatley and Wheatley (1981:33), "as a consequence of this scare, a number of residents of the community stopped eating country food and switched to store bought food." The problem was further intensified by the isolation of the community and the limited wage employment available. Many community members could not afford to buy market foods equal in quantity and nutritional value to their usual country food. "The psychological effect of the apparently sudden presence of an invisible danger in the traditional food supply, coupled with rumours of crippling deformities and death due to
Minamata disease, caused great concern for individuals who had high blood $\mathrm{Hg}$ levels and for community leaders who didn't know which information to believe." Furthermore, the study reported, "the few hunters who continued to harvest and eat country food no longer shared with other family members" (Wheatley and Wheatley, 1981:33).

Similarly, the events surrounding the pilot project for evaluating Inuit traditional food intake in Broughton Island in 1985, when levels of PCBs that exceeded guidelines set by Health Canada were found in the blood of residents, resulted in mixed messages and rumours (Kinloch et al., 1992). Recommendations at that time advised residents not to modify their diet, since health risks from foodborne PCBs did not warrant altering traditional food consumption patterns (Kinloch et al., 1992).

The reported socioeconomic consequences of the Broughton Island pilot project were similar to those in the community of Sugluk. However, in this case, researchers involved in the pilot project informed residents of the purpose of their investigation and the procedures involved in carrying out their work. Though there was no organized communication plan, researchers used the community radio to keep people informed about the research activities (Usher et al., 1995). Yet the Broughton Island pilot project left the community uncertain about what had been discovered. While researchers recommended that residents not change their diet until more studies had been completed to quantify the risks and benefits of country food, front-page stories in the Globe and Mail (Anon., 1988) heightened the fears of the Broughton Island community (Kinloch et al., 1992; Usher et al., 1995). Further contributing to fears and anxieties, Department of Indian Affairs and Northern Development (DIAND) meetings regarding Broughton Island excluded Aboriginal leaders and media, a policy that proved disastrous from the perspective of public relations, and thus risk communication (Kinloch et al., 1992; Usher et al., 1995).

After completing an assessment of health risks from organochlorines in marine mammals in 1995, Health Canada recommended a maximum weekly intake (RMWI) of beluga and ringed seal blubber because of concentrations of chlordane and toxaphene in these tissues (Jensen et al., 1997:361). The maximum quantities initially recommended were lower than quantities actually consumed by many Inuit, which prompted the Inuit Tapirisat of Canada (ITC) to take immediate action and inform regional representatives of the assessments. At a meeting of "contaminants experts" held at the Department of Indian and Northern Affairs Canada in Ottawa a short time later, representatives from all Inuit regions, Health Canada, the Centre for Indigenous Peoples' Nutrition and the Environment (CINE), Department of Fisheries and Oceans, Santé Québec Community Health Department, and the Government of the Northwest Territories Health and Social Services determined that recommending a diet change at that point was premature and unwise. In a public announcement, ITC stated that they had received assessment results 
indicating elevated levels of contaminants in both beluga and ringed seal blubber. However, despite the elevated levels of contaminants, the risks weighed against the known benefits of traditional diets were such that people were advised not to alter their diets (Jensen et al., 1997):

This statement is made with the support and agreement of the leaders from Nunavut, Nunavik, Labrador and Inuvialuit regions...So far as we are aware, the risks to public health from continuing to eat beluga and seal blubber are very small and are outweighed by the benefits to you of these foods. However, Inuit must judge for themselves what is acceptable risk for themselves and their families... (President, ITC - Rosemarie Kuptana, 1995)

A number of communication lessons were learned in the case of assessing the health risk of organochlorines in marine mammals. The fact that all participating agencies were informed of one another's activities meant that they could communicate consistent messages, create more opportunities for information transfer, and determine the types and formats of information most useful to the affected communities (Jensen et al., 1997:362). Social, cultural, and physiological impacts in Sugluk (and, to some extent, Broughton Island) were the result of aspects of poor communication. Communication lessons learned in Broughton Island included the fact that risk assessors might have prevented the unnecessary heightening of anxiety and loss of confidence in general country food safety by evaluating their risk assessment and management options more thoroughly and thinking further about how to disseminate and discuss their research outcomes effectively within the community (Usher et al., 1995). The confidence of the northern residents in the integrity of traditional harvested foods was undermined (Powell and Leiss, 1997). In both Sugluk and Broughton Island, efforts to communicate the impacts of contaminants devalued northern Aboriginals' sense of self because of the role food plays in culture and identity throughout the North, as well as undermining their confidence in the ability of traditional knowledge to diagnose the fitness of country food for consumption. This loss of confidence had the potential to affect the status of Elders, induce a decline in hunting activities, disrupt family roles and traditional activities, and ultimately, influence health and nutritional status (Powell and Leiss, 1997).

\section{COMMUNICATING ABOUT CONTAMINANTS: ACTIVITIES AND PROGRESS}

\section{Research and Practice in Review}

A review of the primary and grey literature relating to the issue of communicating about contaminants and country foods in the Canadian North was conducted in the spring and summer of 2002. We examined all possible accessible sources for pertinent information, documenting communication research activities conducted to date and lessons learned. In general, the primary literature contains little on this specific topic in the Canadian Arctic, although the same issue has fostered great attention in the context of the Great Lakes. One significant federally funded program, the Northern Contaminants Program, has been responsible for the majority of relevant activities in the last decade and a half.

A number of lessons have been learned regarding how to communicate about environmental health issues in the North since the first experiences in the late 1970s and mid 1980s. These lessons can be organized around the basic components of communication as outlined by classic mathematical communication models, such as that of Shannon and Weaver (1949), and adapted into a two-way communication model proposed by Powell and Leiss (1997; Fig. 1), as presented here. We argue that a two-way communication model (supported by many authors, e.g., NRC, 1989; Mulligan et al., 1998) is most appropriate in this context, which involves a number of complicating factors. First is the apparent or actual disparity of views on the risks associated with contaminants in traditional food items in the North, arising from the complex cultural, social, and demographic factors that can influence risk perception and behaviour in these communities. Second is the ongoing need to build trust between risk assessors or scientists and the communities in regard to these issues. Finally, the Aboriginal communities need continuing support to develop local capacity, so that residents can engage in the scientific process of assessing and managing risks in and around their own communities.

As outlined by Powell and Leiss (1997) in reference to the communication model (Fig. 1), the scientific assessment/understanding of risks seeks to translate the scientific findings of the assessment into understandable and meaningful language; explain uncertainties, gaps in understanding, and ongoing and needed research; and build trust in the credibility of the scientific process. Meanwhile, public perception/understanding of a risk helps to inform the "framing" or contextualization of the issue, identify specific concerns and questions the public may have in relation to the risk, and identify conditions that will help the public build the skills and capacity needed to understand and participate in the assessment, communication, and management of the issue. The interaction between the scientific and public "communities" is iterative and linked, and both are integral components of the risk communication process. This process employs various modes of communicating with or engaging individuals in the scientific and northern communities, often with the aid of materials or tools, to bridge gaps across languages, cultures, and worldviews. Ideally, the process is iterative and ongoing: its participants are aware of lessons learned and incorporate this new knowledge into current and future communication practices. 

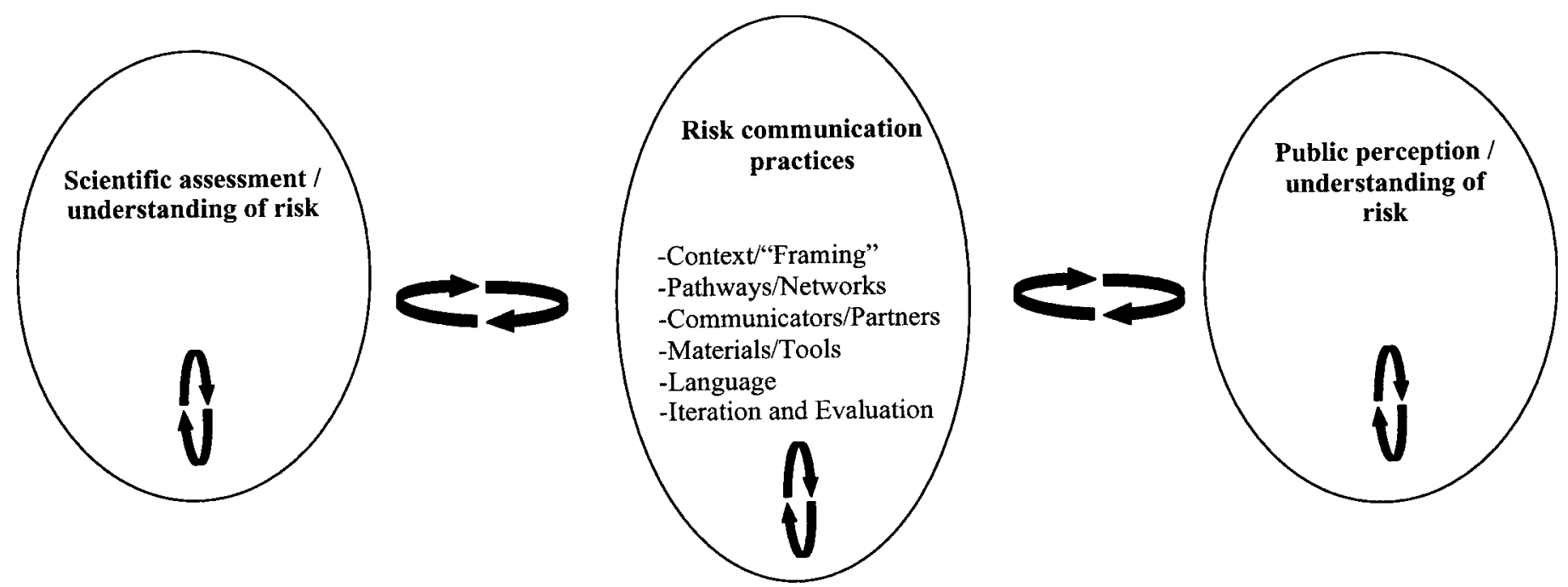

FIG. 1. Two-way communication model (adapted from Powell and Leiss, 1997).

\section{Perceptions, Concern, Behaviours, Context}

Effort has been put into assessing and collecting both qualitative and quantitative data on the perception of contaminants among northern residents. Usher et al. (1995), who reviewed 13 cases in Aboriginal communities from Alaska to Nunavik, found that the communicators' lack of attention to understanding how Aboriginal people perceive contaminants, an invisible problem, had significant impacts on the reception and effect of messages delivered in those communities. Work by Usher et al. (1995), O'Neil et al. (1997), and Poirier and Brooke $(1999,2000)$ shows that Aboriginal communities distrust the information they receive about contaminants in country foods and that their distrust affects their reception of further explanations or clarifications. Various authors (e.g., Usher et al., 1995; LIA, 1997; O'Neil et al., 1997; Furgal, 1999; Poirier and Brooke, 1999, 2000) show the level of concern in communities where contamination events have previously occurred. Residents' concerns include the health of wildlife, the safety of consuming country foods, and human health. Unfortunately, in the cases documented in Sugluk and Broughton Island, little is known about how long the reported impacts of the communication remained.

In work conducted to determine the current impact of contaminant concerns on food behaviour in the North, Furgal et al. (2003a) found that concern over contaminants was not a determinant of food choice in one Labrador community, while Kuhnlein et al. (2003) reported that $42 \%$ of women interviewed in five western Arctic communities indicated "concern over contaminants" as a reason why they did not serve more country foods to their families, and approximately $30 \%$ reported this as one of the top three reasons for this behaviour. Several researchers have previously reported on diet-related behaviours in the North (e.g., Dewailly et al., 1992, 2000; Kuhnlein et al., 2000; Furgal et al., 2003b), but still few have looked in detail at perception and behaviour related to general environmental and health risk-taking to help us understand and put into context the reaction to potential or perceived risks related to country food.

\section{Message}

Little work has been done specifically to identify aspects or types of messages that elicit certain or desired responses among northern populations; however, various sources report some characteristics or attributes of messages that are thought to be more effective in ensuring that messages are understood by an audience. The few pieces of work that have done case reviews or tested pilot communications (e.g., Usher et al., 1995; Grondin and Carron, 1999; Lampe et al., 2000) indicate that good messages are direct, simple, not condescending, put in a personal context for Northerners, accurate, translated into local languages, delivered early and often, and built upon local understandings and knowledge of the issue. Despite these recommendations, little work has been done on such critical issues as translating key words and concepts into (and from) the various Aboriginal languages throughout the North or training interpreters to facilitate communication with Aboriginal Northerners on contaminant issues.

\section{Materials}

Numerous forms of materials have been used to communicate messages on contaminants and country food in the Canadian North. They include, but are not limited to, posters, fact sheets, reports, pamphlets, personal letters, radio public service announcements (PSAs), radio call-in shows, regional video programs, door-to-door or face-toface communication, community meetings, school curriculum materials, and national live television broadcasts (Furgal et al., 2003b). It is important for communicators to consider and identify appropriate media for the target audience. The studies mentioned above recommend the 
use of multiple media to ensure that a message is received, and Northerners suggest the use of methods that facilitate two-way communication to provide comments, feedback, and clarification to audiences (e.g., Lampe et al., 2000). Work conducted in Labrador by Lampe et al. (2000) further suggests some general characteristics for different forms of media that received the greatest attention in Labrador north coast communities.

\section{Pathways}

Effective material is not truly "effective" at delivering a message unless it is distributed through pathways that ensure it will reach and engage the target audience. It appears that "learning by doing" has been the primary approach to determining the most efficient pathways in northern communities. Usher et al. (1995), Furgal (1999), Grondin and Carron (1999), and Lampe et al. (2000) identify the need to consider both formal and informal pathways of delivery and information circulation in northern communities. They recommend use of many carefully selected modes of distribution to ensure that a specific message reaches the target audience. Further, respondents to focus groups on this topic held by Andersen et al. (1999) stressed the need for effective communicators to deliver the messages. These are reported to be individuals who are clear, concise, and confident speakers; consistently and frequently used; approachable; honest and trustworthy; able to accept criticism; knowledgeable about the issues; and understanding of the context around a topic. Given the history and culture of northern communities, we stress the need for face-to-face, verbal dissemination of risk messages in many situations to ensure reception and comprehension by the target audiences.

\section{Audience Specificity}

As outlined in previous sections, research and practice in northern communication have stressed the need to understand and consider the specific attributes, perceptions, and needs of the target audience. Further, as Usher et al. (1995) and Lampe et al. (2000) point out, few examples of communication appear to have clearly identified and targeted a specific audience for messages and planned the best way to reach those target groups. Some exceptions to this include the development of curriculum material for school-aged children on contaminants, environment, and health in the Yukon and Northwest Territories; however, as discussed below, little was done to ensure reception of this material by the target audience.

\section{Reception/Comprehension}

Some proxy measurements of comprehension, such as social expression of the messages (Bruneau et al., 2001) and impacts on behaviour (Wenzel, 2000), have been or are currently being conducted to assess the reception and impact of messages about contaminants. However, it appears that communicators have simply assumed that many basic messages delivered repeatedly in the North have been received and understood in the past. From the lack of attention this aspect of communication has received, it appears that they have also assumed that reception and increased awareness of an issue have indicated comprehension.

\section{Evaluation}

Evaluation is critical to our understanding of all of these aspects of communication about contaminants in the North. As Usher et al. (1995) note for their 13 case reviews from across the North American Arctic, and as Andersen et al. (1999) note for their work reviewing cases in Labrador, little to no review has been conducted on the separate components (message, material, method, reception, impact) of such communications. However, both studies identify the need to conduct and document formal or informal processes of review and evaluation to assess whether communication activities have in fact achieved their desired goals. Lampe et al. (2000) conducted such an evaluation during the development and test dissemination of messages. They found that the length and degree of detail included in basic messages released on these issues needed to be far less than previously included to ensure comprehension among various audiences. They concluded that the pathways and modes of dissemination used previously were not necessarily the most effective in delivering messages to specific audiences (i.e., community meetings were no longer the most effective method to disseminate general messages on these subjects to the larger community population). In general, the results of this work confirmed the need for regional and community-specific evaluation exercises to identify whether objectives of communication efforts were being met. However, it appears that various forms of informal evaluation have taken place across the North through a process of "learning by doing." Although some regions and communities report knowing what "works best" in their location and with their people, little of this experience can be applied in other regions or verified, as little of it is documented in either the grey or scientific literature.

Nonetheless, communication activities related to contaminants have evolved, particularly those conducted through the federally funded contaminants program administered by the Department of Indian and Northern Affairs in Canada (Furgal et al., 2003b). Since the inception of this program, the approach to communications has moved from being purely risk-based to being more balanced, encompassing both benefit and risk information on the same issue. It has evolved from disseminating information on a national scale to working closely with communities to deliver information at the local level and person to person. Finally, it has progressed from being case-specific, delivering information only when there were new research results, to actively engaging communities and 
regions in ongoing communication on these issues and therefore moving from a one-way to a two-way model of risk communication (Furgal et al., 2003b).

\section{IDENTIFIED NEEDS FOR COMMUNICATION ACTIVITIES AND RESEARCH IN THE CANADIAN NORTH}

General perceptions of environmental contaminant issues and concerns have been studied in the Canadian North to some degree (e.g., Usher et al., 1995; O'Neil et al., 1997; Furgal, 1999; Poirier and Brooke, 1999, 2000; Kuhnlein et al., 2000). However, much of this work has been on the population and not the individual level, and little detailed work has focused on the factors that influence individuals' perceptions of these issues. Personal experience, gender, age, socioeconomic status, and profession are all reported to influence perceptions of risk elsewhere (Vaughan, 1995; Slovic, 2000). These factors may also have significant influence on individual perceptions in the North and must be considered in developing and delivering contaminant messages. Many of the "classic" risk questions (e.g., What are the factors influencing individual perception, comprehension, and reception of messages? What are the factors influencing individuals' willingness to comply with health advice on these issues?) have been studied in other environmental health scenarios (e.g., electromagnetic fields in the United States, contaminated sport fish in the Great Lakes) and have aided in communication about these issues. But these questions have never been the focus of studies in the cross-cultural environment of the Canadian Arctic. Thus the concepts of "risk" and its social constructs in Inuit and other Aboriginal societies in the Canadian Arctic may not be very well understood.

Our understanding of how people see the issue is critical to ensure that the communication is best oriented towards the understandings and perspectives of the target audience. The northern perspective on the environment, the importance of country food resources to health and wellbeing, and the ways these and other phenomena are understood (i.e., via traditional knowledge systems and worldviews) suggest that northern Aboriginal populations gather, understand, and use information to make personal decisions about food and health differently from Southerners.

Advances towards understanding the issue from a view more relevant to many northern peoples may be achieved through approaches to research such as the mental mapping conducted by Atman et al. (1994) and others. Although rooted in a more traditional, unidirectional communication model, such approaches require engagement between researchers or communicators and the public and therefore are supported within the philosophy of a two-way communication framework. Further, comprehension resulting from current communication efforts needs to be assessed in order to best orient future communication messages and approaches (Weinstein and Sandman, 1993). This is not to confuse awareness and understanding; individuals may in fact understand the messages delivered but still have another view or opinion on the issue, related to uncertainty or other confounding factors (e.g., lack of alternative food sources). These understandings need to be identified and considered in the development of messages (e.g., not only advising people to restrict consumption of a food item, if warranted, but also suggesting viable alternative food items). As a result of the complex nature of northern communities, some individuals are more easily reached by southern-based communication technologies, while others require more traditional or perhaps new, innovative means through which to connect and exchange information. The factors influencing the extent to which target audiences understand and respond to risk information may be internal (e.g., personal experience with a hazard, perceived importance to the individual) or external (e.g., information provider credibility and trust, format in which the information is delivered) (Connelly and Knuth, 1998). If messages on contaminants and health are to reach target audiences in the North, such as women of childbearing age, then these factors must be identified and addressed in the development of new messages and new methods for their delivery. The North comprises a complex overlay of languages and cultures, and therefore work is needed to ensure the accurate and effective translation of technical concepts and terminology. Currently some confusion exists around basic concepts because of the words used to translate them into different Aboriginal languages. Work conducted by Bruneau et al. (2001) indicated that confusion existed among Nunavimmiut regarding mercury in fish and trichinosis in walrus (Odobenus rosmarus). Recent work conducted by Furgal et al. (2003c) in Labrador and Baffin indicates that when individuals are asked to describe what environmental contaminants are and to provide examples (e.g., wildlife abnormalities, changes in animal behaviour, thin and unhealthy animals, food unfit to eat) in their own words, their responses suggest potentially inaccurate interpretations.

The significant direct and indirect impacts communication on these sensitive issues can have in northern communities indicate the need for retrospective and future reviews of cases, as well as assessments of current impact of communications on health and environment behaviours. Many reports on the impacts of communications in communities have been anecdotal and thus of little help in developing new techniques or approaches to address related problems. It would be prudent in this regard to develop rapid methods for assessing comprehension and impact (short- and long-term) of future communications.

In the planning and development of new communication messages, tools, and methods of assessment, a general communication framework can be adapted for use as a support tool in the North. Such frameworks can act as tools, though not necessarily prescriptive guides, helping communicators to plan, evaluate, and adapt communication 
activities. A variety of existing frameworks for risk management and communication can be used (see Jardine et al., 2003). Similarly, existing general guidelines for risk communication are helpful to communicators in the North (e.g., Hance et al., 1988; NRC, 1989; USEPA, 1990; USDHHS, 1997; Mulligan et al., 1998; Lampe et al., 2000). Many stress the need for evaluation, since without an accurate understanding of what is working or has worked in the past, little basis exists for adaptations to improve reception, comprehension, or acceptance of messages by the target audience (Atman et al., 1994; Usher et al., 1995).

Usher et al. (1995), Peters and Legare (1999), and Furgal (1999) describe a variety of institutional or jurisdictional hurdles that impede efficient management, communication, and evaluation of communication on contaminants issues in the North. These include a simple lack of cooperation between organizations, overlapping jurisdictions, and a lack of clarity about roles and responsibilities in environmental contaminant and health issues in some regions. Therefore, there is a need for coordination among and research on the territorial, regional, and local structures and arrangements to deal with these issues to determine the most effective and efficient formal and informal communication channels (Kasperson, 1986).

Finally, McGrath (2003) argues that Western culture and Inuit society differ in ways that have significant implications for the exchange and sharing of knowledge and are therefore important to mention here. Western (and in this case Southern) culture is information-based, whereas Inuit culture (based on IQ) is relationship-based. One values information in the form of paper, policies, contracts, etc. ("you are what you know"), and the other values the spoken word and quality relationships ("you are who you know"). McGrath's perspective suggests arguments for a more relationship-based or network approach to exchanging knowledge on issues such as contaminants within and between communities, forcing us to look beyond the individual to groups, families, communities, and perhaps regions as the unit of analysis for communication. In a conceptual way, this approach might remove the three boundaries of circles in Figure 1 and encapsulate all individuals in one sphere, with a web of iterative loops. We therefore recommend a much wider approach to discussing, researching, and addressing communication issues in the North that has yet to be realized and adopted by communicators or researchers based in the South. Further, the network approach supports the argument that Aboriginal and non-Aboriginal scientists and communicators must cooperate on this work to better understand the process of translation and exchange across cultures and disciplines. Scientists and communicators need to understand the informal paths of information flow in communities so they can develop mechanisms that support these pathways and use them to communicate information about contaminants and other issues.

\section{CONCLUSIONS}

Despite the evolution in risk communication on these subjects in the Canadian North, a great deal remains to be learned. Given the central importance of country food to Aboriginal society even today in the North, understanding and developing ways to better communicate information on contaminants, country foods, and health is critical. Reports of contamination can undermine Aboriginal confidence in the environment and harvesting activities as being sources of individual and collective well-being.

The lessons about communication learned from the review presented here may be more a "how not to" list than a "how to" list, as the evidence of challenges encountered, although anecdotal in some cases, outweighs the documented reports of best practice to date. The approach to communication under such initiatives as the Northern Contaminants Program has evolved; however, since little evaluative work focused on these subjects has been conducted, we are not yet sure if the messages delivered through these communication strategies have been received and understood. With limited empirical evidence, it is premature to assume that we fully understand the dynamics of risk communication with diverse communities or the most effective ways to engage diverse communities in decision making (Vaughan, 1995).

The advances made on this topic by Usher et al. (1995), O'Neil et al. (1997), and others have been important but still limited in advancing methods of defining and assessing "successful" or "effective" communications or explaining how to overcome existing challenges. The need to develop ways of defining and assessing "success" that are appropriate to these communities and cultural contexts remains. Also, in light of McGrath's (2003) discussion of information-based vs. relationship-based societies, it is evident that the approach to science communications taken in the past, which has assumed the existence of an information-based system, has biased our ability to assess these efforts in a way that is culturally and contextually relevant. Yet, in order to move ahead and improve on past and current approaches, we still need to know what information about important environmental health issues northern communities want, receive, understand, and need-and why.

Leiss (1997:29) describes good risk communication in the following way: "Good risk communication practice seeks to bridge the gap between scientific evaluation of risk and public understanding of risks by ensuring that the meaning of scientific risk assessments is presented in understandable terms to the public - and equally, by ensuring that the nature of the public's concerns is known to and respected by risk managers." One might argue that little true "communication" on the issues of contaminants, food, and health has taken place between scientists, health professionals, and Aboriginal residents in many northern communities; rather, a great deal of scientific information has simply been disseminated. The assumptions that aware- 
ness implies understanding, and that no individual or public reaction (e.g., to a health advisory restricting consumption) implies acceptance, must be refuted with the appropriately gathered empirical evidence if Northerners are to engage in the generation and exchange of information that will provide support for informed decision making on these issues.

\section{ACKNOWLEDGEMENTS}

The authors gratefully acknowledge the support provided by the Canadian Institutes for Health Research to C. Furgal and a project grant from the Northern Contaminants Program (Indian and Northern Affairs Canada) to the authors for this project. We also thank S. Hill and two anonymous reviewers for helpful comments on this manuscript.

\section{REFERENCES}

AMAP (ARCTIC MONITORING AND ASSESSMENT PROGRAMME). 2003. AMAP Assessment 2002: Human health in the Arctic. Oslo, Norway: AMAP. 137 p.

ANDERSEN, F., LAMPE, J., MURPHY, F., FURGAL, C.M., and CRAIG, L. 1999. Country food, nutrition, and health: Developing effective communication strategies in Labrador. In: Kalhok, S., ed. Synopsis of research conducted under the 1998-99 Northern Contaminants Program. Ottawa: Indian and Northern Affairs Canada. 291-294.

ANONYMOUS. 1988. Soviet, European pollution threaten health in Arctic. Globe and Mail, December 15.

ATMAN, C.J., BOSTRON, A., FISCHHOFF, B., and MORGAN, G.M. 1994. Designing risk communications: Completing and correcting mental models of hazardous processes, Part 1. Risk Analysis 14:779-788.

BARRIE, L.A., GREGOR, D., HARGRAVE, B., LAKE, R., MUIR, D., SHEARER, R., TRACEY, B., and BIDLEMAN, T. 1992. Arctic contaminants: Sources, occurrence and pathways. The Science of the Total Environment 122(1-2):1-74.

BERKES, F., and FARKAS, C.S. 1978. Eastern James Bay Cree Indians: Changing patterns of wild food use and nutrition. Ecology of Food and Nutrition 7:155-172.

BRAUNE, B., MUIR, D., DE MARCH, B., GAMBERG, M., POLE, K., CURRIE, R., DODD, M., DUSCHENKO, W., EAMER, J., ELKIN, B., EVANS, M., GRUNDY, S., HEBERT, C., JOHNSTONE, R., KIDD, K., KOENIG, B., LOCKHART, L., MARSHAL, H., REIMER, K., SANDERSON, H., and SHUTT, L. 1999. Spatial and temporal trends of contaminants in Canadian Arctic freshwater and terrestrial ecosystems: A review. The Science of the Total Environment 230:145-207.

BRUNEAU, S., FURGAL, C.M., and DEWAILLY, É. 2001. Incorporation of scientific knowledge into Inuit (traditional and lay) knowledge in Nunavik. In: Kalhok, S., ed. Synopsis of research conducted under the 1998-99 Northern Contaminants Program. Ottawa: Indian and Northern Affairs Canada. $291-293$.
CONDON, R.G., COLLINGS, P., and WENZEL, G. 1995. The best part of life: Subsistence hunting, ethnicity, and economic adaptation among young adult Inuit males. Arctic 48(1):31-46.

CONNELLY, N.A., and KNUTH, B.A. 1998. Evaluating risk communication: Examining target audience perceptions about four presentation formats for fish consumption health advisory information. Risk Analysis 18(5):649-659.

DEWAILLY,É., NANTEL, A., BRUNEAU, S., LALIBERTÉ, A., FERRON, L., and GINGRAS, S. 1992. Breast milk contamination by PCDDs, PCDFs and PCBs in Arctic Quebec: A preliminary assessment. Chemosphere 25(7-10):1245-1249.

DEWAILLY, É., AYOTTE, P., BRUNEAU, S., SCHWARTZ, H., GREY, M., WEBER, J., LEBLANC, A., PROULX, J., GRONDIN, J., and MIRAULT, M.E. 2000. Mercury in Salluit: Temporal trend and interaction with selenium. In: Kalhok, S., ed. Synopsis of research conducted under the 1999-2000 Northern Contaminants Program. Ottawa: Indian and Northern Affairs Canada. 32-36.

FREEMAN, M.M.R. 1992. The nature and utility of traditional ecological knowledge. Northern Perspectives 20(1):9-12.

FURGAL, C.M. 1999. Addressing decision-making capacity in Labrador: The case of health advisories and the Labrador Inuit. In: Craig, L., ed. Eco-Research Avativut/Ilusivut Research Program, Final Report. Beauport, Québec: Unité de recherche en santé publique, CHUQ-Pavillon CHUL (Centre de santé publique de Québec). 69-75.

FURGAL, C.M., BERNIER, S., GODIN, G., and DEWAILLY, É. 2003a. Determinants of food choices in Labrador. In: Synopsis of research conducted under the 2001-2003 Northern Contaminants Program. Ottawa: Indian and Northern Affairs Canada. 86-116.

FURGAL, C.M., KALHOK, S., LORING, E., and SMITH, S., eds. 2003b. Knowledge in action. Canadian Arctic Contaminants Assessment Report II (CACAR II). Ottawa: Indian and Northern Affairs Canada. 90 p.

FURGAL, C.M., MYERS, H., and POWELL, S. 2003c. Assessing awareness, comprehension, and perception of contaminants issues in two regions of the Canadian North. In: Synopsis of research conducted under the 2001 - 2003 Northern Contaminants Program. Ottawa: Indian and Northern Affairs Canada. 399-403.

GRONDIN, J., and CARRON, H. 1999. Strategies and challenges for effective communication in Nunavik and Labrador. In: Craig, L., ed. Eco-Research Avativut/Ilusivut Research Program, Final Report. Beauport, Québec: Unité de recherche en santé publique, CHUQ-Pavillon CHUL (Centre de santé publique de Québec). 84-90.

HANCE, B.J., CHESS, C., and SANDMAN, P. 1988. Improving dialogue with communities: A risk communication manual for government. New Brunswick, New Jersey: Department of Environmental Protection, Environmental Communication Research Program.

JARDINE, C.G., HRUDEY, S.E., SHORTREED, J.H., CRAIG, L., KREWSKI, D., FURGAL, C., and McCOLL, S. 2003. Risk management frameworks for human health and environmental risks. Journal of Toxicology and Environmental Health Reviews 6(6):569-719. 
JENSEN, J., ADARE, K., and SHEARER, R., eds. 1997. Canadian Arctic Contaminants Assessment Report I (CACAR I). Ottawa: Indian and Northern Affairs Canada. 459 p.

JETTÉ, M. 1994. A health profile of the Inuit: Report of the Santé Quebec health survey among the Inuit of Nunavik, 1992. Montreal: Ministère de la Santé et des Services sociaux, Gouvernement du Québec.

JOHNSON, B.B., and COVELLO, V.T. 1987. The social and cultural construction of risk. Dordrecht, The Netherlands: D. Reidel Publishing Company.

KASPERSON, R.E. 1986. Six propositions on public participation and their relevance for risk communication. Risk Anyalsis 6(3):275-278.

KINLOCH, D., KUHNLEIN, H., and MUIR, D.C.G. 1992. Inuit foods and diet: A preliminary assessment of benefits and risks. The Science of the Total Environment 122:247-278.

KUHNLEIN, H.V., and SOUEIDA, R. 1992. Use and nutrient composition of traditional Baffin Inuit Foods. Journal of Food Composition and Analysis 5:112-126.

KUHNLEIN, H.V., RECEVEUR, O., CHAN, H.M., and LORING, E. 2000. Assessment of dietary benefit/risk in Inuit communities. Ste-Anne-de-Bellevue, Québec: Centre for Indigenous Peoples' Nutrition and Environment (CINE).

KUHNLEIN, H., DICKSON, C., ARMSTRONG, C., and PACI, C. 2003. Food choice decisions by Western Arctic women and children, Year 2. In: Synopsis of research conducted under the 2001 - 2003 Northern Contaminants Program. Ottawa: Indian and Northern Affairs Canada. 122-129.

LAMPE, J., MURPHY, F., FURGAL, C., and CRAIG, L. 2000. Country food, nutrition and health: Developing effective communication strategies in Labrador (Year 2). In: Kalhok, S., ed. Synopsis of research conducted under the 1999-2000 Northern Contaminants Program. Ottawa: Indian and Northern Affairs Canada. 271-280.

LIA (LABORADOR INUIT ASSOCIATION). 1997. Environmental health study. Final report of the Eco-Research Project. Nain, Labrador: Labrador Inuit Association.

LEISS, W. 1997. A diagnostic for risk communication failures. In: Powell, D., and Leiss, W., eds. Mad cows and mother's milk: The perils of poor risk communication. Montreal: McGillQueen's University Press. 26-40.

McGRATH, J. 2003. Interview with Janet McGrath. Meridian (Spring):5-9. Ottawa: Canadian Polar Commission.

MUIR, D.C.G., BRAUNE, B., DE MARCH, B., NORSTROM, R., WAGEMANN, R., LOCKART, L., HARGRAVE, B., BRIGHT, D., ADDISON, R., PAYNE, J., and REIMER, K. 1999. Spatial and temporal trends and effects of contaminants in the Canadian Arctic marine ecosystem: A review. The Science of the Total Environment 230:83-144.

MULLIGAN, J., McCOY, E., and GRIFFITHS, A. 1998. Principles of communicating risks. Working Paper \#4. Calgary: Macleod Institute for Environmental Analysis, University of Calgary.

NATIONAL RESEARCHCOUNCIL. 1989. Improving risk communication. Washington, D.C.: National Academy Press. 175.

O'NEIL, J.D., ELIAS, B., and YASSI, A. 1997. Poisoned food: Cultural resistance to the contaminants discourse in Nunavik. Arctic Anthropology 34(1):29-40.
PETERS, E., and LEGARE, A. 1999. Management of food chain contaminant issues in Nunavik and Labrador: The role of Inuit and non-Inuit organizations. In: Craig, L., ed. Eco-Research Avativut/Ilusivut Research Program Final Report. Beauport, Québec: Unité de recherche en santé publique, CHUQ-Pavillon CHUL (Centre de santé publique de Québec). 65-69.

POIRIER, S., and BROOKE, L. 1999. Inuit perceptions of contaminants, environmental knowledge and land use in Nunavik: In: Craig, L., ed. Eco-Research Avativut/Ilusivut Research Program Final Report. Beauport, Québec: Unité de recherche en santé publique, CHUQ-Pavillon CHUL (Centre de santé publique de Québec). 43-53.

2000. Inuit perceptions of contaminants and environmental knowledge in Salluit, Nunavik. Arctic Anthropology 37(2): $78-91$.

POWELL, D., and LEISS, W., eds. 1997. Mad cows and mother's milk: The perils of poor risk communication. Montreal: McGillQueen's University Press.

SHANNON, E., and WEAVER, W. 1949. The mathematical theory of communication. Urbana, Illinois: University of Illinois Press.

SLOVIC, P. 2000. The perception of risk. London: Earthscan Publications Ltd.

USEPA (U.S. ENVIRONMENTAL PROTECTION AGENCY). 1990. Communicating environmental risks: A guide to practical evaluations. Risk Communication Series. Washington, D.C.: USEPA.

USDHHS (U.S. DEPARTMENT OF HEALTH AND HUMAN SERVICES). 1997. An evaluation primer on health risk communication programs and outcomes. Environmental Health Policy Committee, Subcommittee on Risk Communication and Education. Washington, D.C.: USDHHS.

USHER, P.J. 2000. Traditional ecological knowledge in environmental assessment and management. Arctic 53(2): $183-193$.

USHER, P., BAIKIE, M., DEMMER, M., NAKASHIMA, D., STEVENSON, M., and STILES, M. 1995. Communication about contaminants in country food: The experience in Aboriginal communities. Ottawa: Inuit Tapirisat of Canada.

VAN OOSTDAM, J., GILMAN, A., DEWAILLY,É., USHER, B., WHEATLEY, B., KUHNLEIN, H., NEVE, S., WALKER, J., TRACEY, B., FEELEY, M., JEROME, J., and KWAYNICK, B. 1999. Human health implications of environmental contaminants in the Arctic: A review. The Science of the Total Environment 230:1-82.

VAN OOSTDAM, J., DONALDSON, S., FEELEY, M., and TREMBLAY, N. 2003. Toxic substances in the Arctic and associated effects - human health. Canadian Arctic Contaminants Assessment Report II (CACAR II). Ottawa: Indian and Northern Affairs Canada. 127 p.

VAUGHAN, E. 1995. The significance of socioeconomic and ethnic diversity for the risk communication process. Risk Analysis 15(2):169-180.

WEINSTEIN, N.D., and SANDMAN, P.M. 1993. Some criteria for evaluating risk messages. Risk Analysis 13(1):103-114.

WENZEL, G. 2000. Inuit response to environmental contaminants information: The Cape Christian-Clyde River Case. In: Kalhok, S., ed. Synopsis of research conducted under the 1999-2000 
114 • C.M. FURGAL et al.

Northern Contaminants Program. Ottawa: Indian and Northern Affairs Canada. 301-308.

WHEATLEY, B. 1993. A new approach to assessing the effects of environmental contaminants on Aboriginal peoples. Paper presented to the 9th International Congress on Circumpolar
Health, 20-25 June 1993, Reykjavik, Iceland. Available from the senior author.

WHEATLEY, B., and WHEATLEY, M.A. 1981. The effect of eating habits on mercury levels among Inuit residents of Sugluk, P.Q. Etudes/Inuit/Studies 5(1):27-43. 